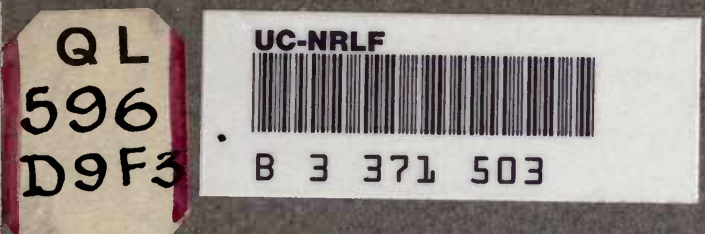




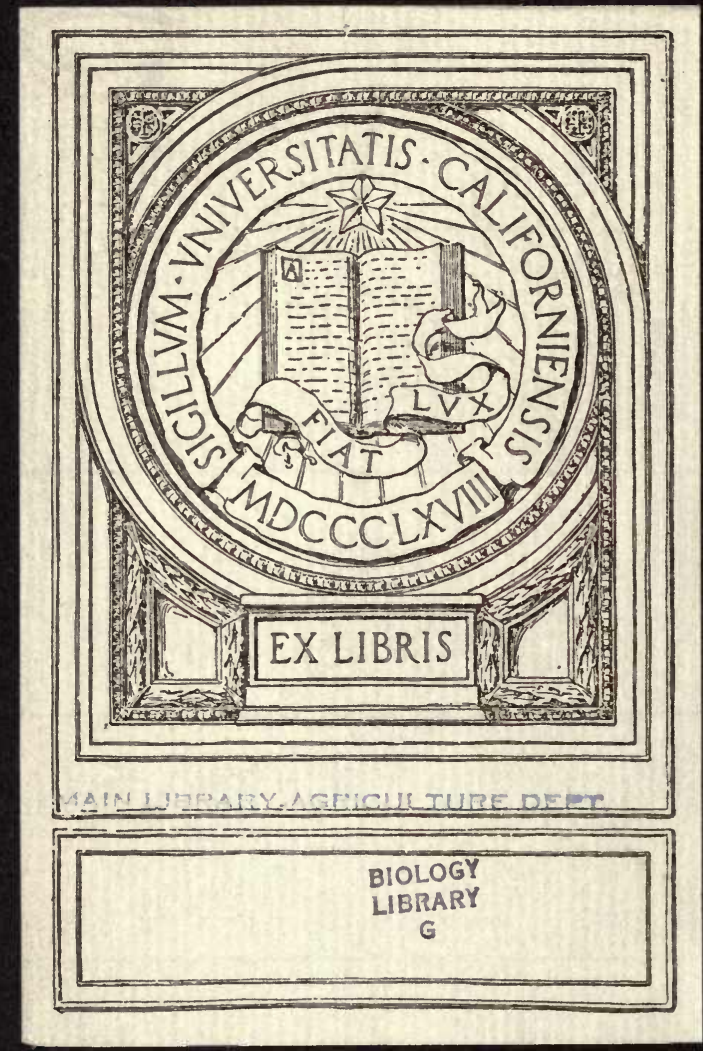




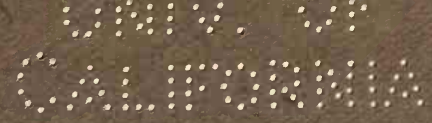

\title{
The North American species of COELAMBUS
}

\author{
By H. C. FALL
}

PUBLISHED BY

JOHN D. SHERMAN, Jr. MOUNT VERNON, NEW YORK 1919 
Copyright, 1919

John D. Sherman, Jr. 


\title{
The North American Species of Coelambus
}

\author{
By H. C. Fall
}

The members of the genus Coelambus possess a facies which makes them tolerably easy of recognition at sight; they may however be distinguished at once and with certainty from allied genera by the raised line obliquely crossing the epipleurae at base. Our species are fairly numerous, the number known to me at present being nearly twice that indicated in the Henshaw List, all of which except the infuscatus of Sharp, are represented in the material studied. C. princeps, recently described from Florida by Blatchley is not a Coelambus, but belongs in all essentials to Pachydrus, a genus represented by a small number of species in the Antilles and Tropical America. Through the kindness of its author I have been permitted to examine the type, which seems to me distinct from any of the species given in Sharp's Monograph.

In the table of species which follows, some emphasis has been placed on the degree of dilatation of the male tarsi. Since in several species the tarsi of the male are very little wider than in the female, or even narrower than in females of other species; it is necessary to have a sure means of recognizing the males. In the greater number of species the thickening of the anterior claw of the front tarsus of the male, though sometimes feeble, is sufficient at once to reveal the sex, but when this character fails it will be useful to remember that in the male the basal two joints of the front and middle tarsi are (one or both) perceptibly wider than the third, while in the female the first three joints are of equal width.

Unless otherwise stated, the types of all new species are in the writer's collection.

Wherever the order of species differs in the text from that in the table, the former should be followed in cataloguing or in a cabinet arrangement.

1. Front margined (except farctus), body broadly ovate and very convex beneath (except intermedius), color beneath entirely rufous or rufotestaceous.

Front not margined (except masculinus and fastidiosus), form less broad and less convex, body beneath black (except laccophilinus and sylvanus, size generally larger. 


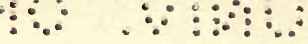

$\therefore: \because \because \because \because \vdots \vdots \vdots \cdots \cdots \cdots$

2. Last ventral foveate in $\delta$, front tarsi of $\delta$ distinctly dilated, size small ( 2 to $2.4 \mathrm{~mm}$.).

Front margined, elytra with longitudinal lateral carina, color yellow with black elytral maculation, metasternum, coxal plates and sides of abdomen at base coarsely punctate, remainder of abdomen very finely and densely so.

acaroides

Elytra piceous black with narrow side markings broadening into a rounded lobe at middle, reddish brown.

var. marginipennis

Front not margined, elytra not carinate, color of elytra uniformly red brown, head and thorax paler, body beneath densely finely subrugosely punctate throughout.

farctus

Last ventral not foveate in the male, front tarsi variable, size larger ( 2.6 to $3.2 \mathrm{~mm}$.).

Form broad and very convex.

Punctures of elytra unequal, front tarsi of $\delta$ dilated......hydropicus

Punctures of elytra nearly uniform in size, elytra reddish

brown with obscure confluent markings, front tarsi of $\delta$ not dilated.

punctatus

Form less broad and less convex, approaching in these respects

the species which follow. intermedius

3. Color above uniformly reddish brown or castaneous, beneath not black, or only partially so.

Color above flavo-, rufo- or piceotestaceous, or piceous brown, the elytral disk often with broad nubilous markings which are never distinctly vittate, body beneath black.

Color above fulvo- or rufotestaceous, elytra with distinct vittiform markings (except"in some forms of impressopunctatus.).

4. Size a little larger, form somewhat broader and more convex, disparity in elytral punctures less evident, females opaque. laccophilinus Size rather smaller, a little narrower and less convex, elytral punctures evidently unequal toward the base, females not opaque: sylvanus

5. Elytra with intermixed coarser and finer punctures, which are more or less generally diffused; elytra without markings.

Elytra nearly uniformly punctate, exception being made of the more or less evident sutural and two discal irregular series of coarser punctures visible, especially toward the base, in many species.

6. Front and middle tarsi of male narrow, not or scarcely wider than in the female.

Size smaller ( 2.6 to $3 \mathrm{~mm}$.), form a little broader, dual punctuation of elytra not very evident posteriorly. turbidus

Size larger (3.4 to $4 \mathrm{~mm}$.), form narrower, dual punctuation distinct throughout.

dispar

Front and middle tarsi of male distinctly wider than in the female, the second joint conspicuously widest.

Form a little broader, color varying from dull yellow to brown.

(New England to Lake Superior.) compar

Form a little more elongate, color darker. (California.)......nigrescens

7. Front tarsi of male at most only moderately dilated. 8 Front tarsi of male broadly dilated, nearly or quite as wide as the apical width of the tibia. 
8. Middle tibiae of male unmodified, femora similar in the sexes, the posterior ones finely longitudinally sub-strigose like the others.

Middle tibiae of male sinuate within and produced inwardly at apex; front and hind femora dissimilar in the sexes, the latter without fine strigosity in either sex.

pedalis

9. Form narrow, twice as long as wide, or even more, front claw of anterior male tarsi not perceptibly modified, color of elytra nearly uniform piccotestaceous to piceous brown.

Front tarsi of male narrowly dilated, size smaller $(2.8 \mathrm{~mm}$. $)$........ artus

Front tarsi of male broader, size larger ( 3.7 to $4.2 \mathrm{~mm}$.).......... sharpi

Form less elongate, varying from very distinctly less than, to nearly twice as long as wide, front claw of anterior male tarsi perceptibly modified. (Male of ovoideus not yet known.)

10. Front tarsi of male scarcely wider than the female, the anterior claw unmodified; size small (3.I to $3.3 \mathrm{~mm}$.), (Lake Superior, H.

B. Territory, Manitoba.) suturalis

Front tarsi of male rather narrowly dilated, but evidently wider than in the female; anterior claw of front tarsi in the male slightly thicker and more abruptly bent at base; (ovoideus provisionally placed, of not yet known.)

Front tarsi of male wider, the second joint conspicuously dilated, anterior claw evidently modified.

11. Species of the Lake Superior and Manitoba region.

Color above nearly uniformly rufotestaceous, the sutural edge

of the elytra blackish; length $3.5 \mathrm{~mm}$. (Lake Superior.)

ovoideus

Color above nearly uniformly piceo-testaceous, the elytral suture

fainty paler basally; length 3.5 to $4 \mathrm{~mm}$. (Manitoba.). canadensis

Color of thorax often in great part blackish, of elytra pale testaceous with a large, sharply defined piceous discal blotch behind the middle. (Dakota; Manitoba.) sellatus Species of the Pacific Coast and Sonoran region.

Color above testaceous with large elytral cloud extending nearly to base; form slightly narrower, the size as a rule, a little smaller than the next. lutescens

Color nearly as in the preceding but with the elytral cloud less extended basally as a rule; the elytral markings very variable in development, sometimes nearly wanting. medialis Color above yellowish testaceous, elytra with faint posterior dorsal cloud. Length $3.6 \mathrm{~mm}$. (Utah.) virgo

12. Brownish yellow, the elytra darker with obscure discal markings behind the middle. (Washington; Oregon.) obscureplagiatus

13. Front tarsi of male less widely dilated, not quite as wide as the tibial apex. collatus Front tarsi of male subequal in width to the apex of the tibia.

Head with vertex and sides of front more or less piceous.

Size smaller $\left(3^{1 / 2} \mathrm{~mm}\right.$. more or less.) patruelis

Size larger $(5 \mathrm{~mm}$.) infuscatus

Head entirely pale except for a small transverse occipital spot.

Size larger (over $4 \mathrm{~mm}$.) and form more elongate.

Femora of male normally feebly sinuate beneath near the knee, tibiae not pedunculate. nubilus 
Femora of male strongly sinuate beneath at apex, tibiae pedunculate at base.

Size smaller (less than $4 \mathrm{~mm}$.), form broader; color generally paler with better defined elytral clouds behind the middle.

fraternus

14. Elytra without impressed lines.

Elytra with more or less evident impressed lines in basal half, at least in the male, feeble or wanting in the female.

15. Punctures of elytra evidently unequal. .....................................................16

Punctures of elytra denser and nearly uniform in size. ..............................17

16. Last ventral with an obtuse tumidity each side, more prominent in the male. tumidiventris Last ventral not tumid. punctilineatus

17. Clypeus margined.

Form more distinctly obovate, sides of thorax not continuous with those of the elytra. masculinus

Form less distinctly obovate, thorax larger, sides straight, slightly sinuate, continuous with sides of elytra'. fastidiosus Clypeus not margined.

18. Sides of thorax feebly divergent posteriorly, not continuous with sides of elytra: elytral vittae narrow, much abbreviated in front. semivittatus

Sides of thorax normally divergent, nearly continuous with sides of elytra.

Size smaller ( 3.6 to $4 \mathrm{~mm}$.), claws of front tarsi (ठో) unusually elongate, not very unequal in length or thickness. hudsonicus Size larger ( 5 to $5.8 \mathrm{~mm}$.)

Form broader, surface beneath alutaceous in both sexes, claws of front tarsi $\left(\delta^{*}\right)$ very unequal............................ unguicularis Form more elongate, surface beneath not alutaceous, claws of front tarsi ( $\left.\delta^{\star}\right)$ stout, rather short, equal oregonus

19. Size larger ( 4.5 to $5.5 \mathrm{~mm}$.), color varying from pale yellow, with vittate elytra to nearly uniformly piceous; punctuation very coarse with intermixed fine punctures, less obvious in the female.

impressopunctatus

\section{C. acaroides Lec.}

Rotundate oval, rufotestaceous, body beneath often darker, brownish or even piceous with the prothorax and abdominal apex pale; elytra with the suture narrowly, a broader more or less abbreviated subsutural stripe (often interrupted), and two external discal spots, blackish; the markings are, however, very variable through confluence or suffusion. Antennae and legs pale, the tarsi sometimes dusky. Head and thorax finely, not very closely punctate; elytra more coarsely and closely and very evenly so. Coxal plates very coarsely closely punctate, abdominal segments very minutely densely punctulate and dull, the basal segments at sides with scattered shallow coarser punctures. Clypeus very finely margined; elytra with a fine acute submarginal carina extending forward from the niddle but not attaining the base. Length 2.1 to $2.4 \mathrm{~mm}$.; width $\mathrm{I} .3$ to $\mathrm{I} .5 \mathrm{~mm}$.

Var. marginipennis Blatch.

Similar in all essentials to the typical form, but with an extreme suffusion of 
the elytral spots, leaving only a pale lateral margin which broadens into a rounded lobe at the middle. Blatchley in his description says there is no elytral carina, it is however, quite as distinct in a typical example before me as in the usual acaroides form.

The types of acaroides were from Illinois and Kentucky. Specimens before me are from Illinois; Miss; Fedor, Texas; Winnfield La. (Pilate.) It is reported from Cincinnati, Ohio, by Dury, and is on the Iowa List(Wikham.) The variety occurs in Florida (Sarasota and Dunedin-Blatchley.)

The front and middle tarsi of the male are distinctly dilated, and there is in this sex a small discal excavation of the last ventral from the anterior margin of which project backward two approximate porrect slender spines. This remarkable structure exists in the following species, but so far as I know has no parallel elsewhere in the family, and seems to have been entirely overlooked.

\section{C. farctus Lec.}

Rotundate oval, feebly shining above, opaque beneath, general color reddish brown, the elytra darker brown with the side margins suffusedly paler, outer joints of antennae, tarsi and frequently the basal half of the abdomen more or less infuscate. Head not margined in front, finely densely punctate. Prothorax similarly punctate, a few interspersed coarser punctures along the base. Elytra finely, closely punctate, with numerous intermixed coarser ocellate punctures in the basal half, these becoming less numerous or nearly disappearing posteriorly. Body beneath very densely punctate, the ventral segments very minutely so, the metasternum and coxal plates more coarsely so. Length 2.2 to $2.3 \mathrm{~mm}$. ; width $\mathrm{I} .35$ to $\mathrm{I} .4 \mathrm{~mm}$.

Le Conte's type was from Massachusetts, and all the specimens at hand are from Tyngsboro, Mass., where I have taken it somewhat sparingly in a small woodland pond. Crotch recorded it from New Jersey also and recent collectors report its occurrence at Lakehurst in that state.

The four anterior tarsi are quite distinctly dilated in the male, evidently narrower in the female. The last ventral of the male shows the same median excavation and porrect spinules as in acaroides, but the excavation is here rather larger and the spinules less approximate.

\section{C. punctatus Say.}

Broadly rotundate ovate; very convex, especially beneath, head thorax and body beneath rufotestaceous, the elytra usually duller brownish yellow, the disk with obscure fuscous markings which are sometimes feebly defined, but usually broadly suffused; base and apex of thorax blackish; antennae and legs entirely rufotestaceous. Punctuation above strong, close and nearly uniform, beneath coarse and close. Tarsi narrow, not appreciably broader in the male. Length 2.8 to $3 \mathrm{~mm}$.; width 1.7 to $1.9 \mathrm{~mm}$.

A common and well known species widely dispersed in Canada and the northern half of the United States from New England to the 
Pacific coast. Specimens are known to me or reliably reported from Maine, (York Beach;) Massachusetts (Marion, Tyngsboro;) New York (Adirondack Mountains; Buffalo;) New Jersey ("all sections of state"-Smith's List;) Southwestern Pennsylvania (Hamilton List;) Ohio; N. Illinois; Wisconsin; Central and Northern Indiana (Blatchley;) Ottawa, Canada; Cochrane, N. Ontario (Notman;) Lake Superior; Winnipeg, Manitoba (Wallis,) Kansas; "Northwest Territory” (Say's description;) British Columbia (Peachland-Wallis;) Seattle, Washington (O. B. Johnson;) Carlin, Nevada.

This species has been held by most writers to be at most only a variety of the European inaequalis. This view however is not shared by Sharp who says of punctatus "rather different in outline being broader in the middle and so less parallel in form, with the punctuation of the elytra rather dense, and the upper surface without distinct contrasts of color." The difference in form stated by Sharp seems to have some slight basis in fact, though rather difficult of appreciation by the unimaginative student. Personally I have seen no American examples that in brightness of makings could be considered as typical inaequalis, Crotch however mentions "two specimens from Illinois marked precisely as in the European species."

\section{C. hydropicus Lec.}

Broadly ovate, convex, nearly similar in form to punctatus but a little more elongate, flavo-or rufotestaceous, outer joints of the antennae and front and hind margins of thorax more or less infuscate; elytra dull yellow, disk with broadly confluent fuscous shades, which in the more definitely marked examples leave the sides and transverse basal and postmedian series of spots or dashes, yellow. Punctuation above and beneath still denser than in punctatus, and on the elytra distinctly dual in character, especially baso-medially; not very obviously so in punctatus. Front and middle tarsi very distinctly dilated in the male, the claws not sexually modified. Length 2.8 to $3.2 \mathrm{~mm}$; width I.7 to I.8 $\mathrm{mm}$.

California-Middle and Southern. Le Conte's type is from San Diego. Specimens before me are from Pomona, Pasadena, Santa Margarita (San Luis Obispo Co.-Martin) Guerneville, Sonoma Co. (Blaisdell,) and Vine Hill, Contra Costa Co. (Blaisdell.)

The general similarity to the well known punctatus, combined with the dilated male tarsi render this species easily recognizable. It is thus far known to me only from California and I have as yet seen no specimens of punctatus from this state, though its proximity both to the north and east make its ultimate discovery there not unlikely.

\section{C. intermedius sp. nov.}

Oval, moderately elongate, yellowish testaceous, head (more or less) and front and hind margins of thorax infuscate; elytra with broad suffused fuscous clouds which leave only the side margins and some indistinct subbasal and 
postmedian spots paler. Integuments polished throughout. Antennae scarcely infuscate apically. Head margined in front. Punctuation of head and thorax fine, not very close; elytra more coarsely and closely punctate. Body beneath rather strongly and not very closely punctate, the punctures coarser on the coxal plates as usual. Length $2.6 \mathrm{~mm}$.; width $1.4 \mathrm{~mm}$.

The type was collected in Alameda Co., California by Koebele. The specimen is, I think, a male, though the tarsi are only very moderately dilated. A second specimen is from Dalles, Oregon.

This litle species is by the margined front allied to those which precede, but is distinctly less convex both above and beneath, and has the moderately elongate oval form of most of the species which follow.

\section{Iaccophilinus Lec.}

Ovate, pointed behind, moderately convex, rufocastaneous, coxal plates and base of abdomen sometimes infuscate. Integuments sparsely rather finely punctate, strongly shining in the male, alutaceous and opaque and more finely punctate in the female. Length 2.8 to $3.1 \mathrm{~mm}$.; width 1.65 to $1.75 \mathrm{~mm}$.

Described from Detroit, Michigan; known to me also from Tyngsboro, Mass., Peekskill, N. Y. (Sherman), and Indiana (Blatchley.) It is also recorded by Smith in the New Jersey List.

This species is similar in many respects to the next, but is a little larger, broader and more convex, and. with less inequality in size of punctures. The front and middle tarsi are very distinctly wider in the males than in the females, the disparity being much less marked in sylvanus.

\section{C. sylvanus Fall.}

Form rather narrowly ovate, widest before the middle, moderately convex, glabrous, both sexes shining; color castancous, the antennae legs and under side of head and prothorax brighter rufous. Head and prothorax finely sparsely punctulate, the latter more strongly and closely so along the front and rear margins. Elytra widest a little behind the base, sides continuous in outline with the prothorax; punctuation not very close, consisting of intermixed moderately coarse and much finer punctures. Metasternum, coxal plates and sides of the basal ventral segments sparsely punctate, the punctures gradually diminishing in size from front to rear. Front and middle tarsi of male only moderately dilated, a little narrower in the female; claws small and slender, unmodified in the male. Length 2.5 to $2.7 \mathrm{~mm}$.; width 1.35 to $1.45 \mathrm{~mm}$.

New York (Peekskill-Sherman.)

Nearly allied to laccophilinus but smaller, narrower and less convex (not "more convex" as was stated by mistake in the original description), and with less dilated male tarsi, the sexual difference in this respect not very marked.

\section{C. turbidus Lec.}

Regularly oval, moderately convex, widest at middle, above dull yellowish to brownish or piceotestaceous, without markings; the head, thorax anteriorly, and side margins of elytra a little brighter in color; integuments polished in both 
sexes; antennae with outer joints lightly infuscate. Head and thorax finely sparsely punctate, a few coarser punctures along the base of the latter. Elytra with a dual system of finer and coarser punctures, which is, however, not very strongly marked, the disparity becoming quite feeble posteriorly. Body beneath black, metasternum, coxal plates and sides of abdomen at base coarsely, not densely punctate, venter elsewhere finely sparsely punctate; under side of prothorax, epipleurae and legs pale. Length 2.7 to $3 \mathrm{~mm}$; width 1.5 to $1.75 \mathrm{~mm}$.

Described by Le Conte from Massachusetts. Crotch says more specifically, "Boston." It occurs rarely at Tyngsboro, Mass., and other Massachusetts specimens in my collection are labeled Westport, Berkeley and Fall River (N. S. Easton). I have also before me examples from Vermont, Montreal, Can.; Winnipeg, Man. (J. B. Wallis), and Ag. Coll., Miss. (H. E. Weed.) It is reported from Staten Island (Leng), and from Indiana (Blatchley.)

\section{C. dispar Lec. (=dissimilis G. \& H.)}

Moderately elongate, oval, dull yellow to brownish testaceous, head and thorax commonly brighter rufotestaceous, the typical dorsal discal clouds feebly defined on the elytra in the light colored examples, but scarcely at all evident in the darker specimens; trunk black beneath; integuments polished throughout in both sexes; outer joints of antennae lightly infuscate, with their bases paler. Head and prothorax finely sparsely punctate, the latter with a few coarser punctures near the base. Elytra with conspicuously intermixed fine and much coarser punctures over the greater portion of the disk, the punctures closer and more nearly equal in size at apex. Metasternum, coxal plates and the sides of the basal ventral segments coarsely punctate. Length 3.4 to $4 \mathrm{~mm}$.; width 1.85 to $2.15 \mathrm{~mm}$.

This species is widely dispersed in the northern United States and Canada. Described from Lake Superior. Specimens before me are from Esopus, N. Y.; Phila Neck, Pa.; South Haven, Mich.; Evanston, Ind. ; N. Ill. ; Glencoe, Ill. ; Rochester, Minn.; St. Louis, Mo. ; Winnipeg, Man.; Kamloops, B. C. It is recorded also in the New Jersey, District of Columbia and Iowa Lists.

In some 30 or 40 specimens examined there are no obvious sexual differences, the tarsi being narrow and of the female type in all, though there can be little doubt that both sexes are present.

\section{C. compar sp. nov.}

Elongate oval, very similar in form and size to the preceding species, and like that, varying in color from dull yellow or rufotestaceous to fuscotestaceous or brownish, the elytra, however, without trace of nubilous markings which are sometimes somewhat defined in dispar, antennae infuscate from about the middle. Elytra with intermixed punctuation, the coarser punctures, however, are smaller than in dispar, and the disparity is therefore less marked and is not very evident except in the baso-sutural region. The males are polished, the females may be either shining or dull, the latter as usual more finely punctate. In the male the front and middle tarsi are distinctly broader, the second joint rather conspicuously widest and triangular, the third joint about as long as wide and very slightly wider than the basal joint, the anterior claw of the front 
tarsus thicker and more strongly bent. In the female the tarsi are narrow with joints I-3 equal in width. Length 3.6 to $4 \mathrm{~mm}$; width 1.95 to $2.15 \mathrm{~mm}$.

The type of this species is a male taken by the writer at Tyngsboro, Mass., 7-2I-06. Similar examples from Bennington Co., Vt., are in the Roberts and Sherman Collections. Mr. Sherman has also taken it at Starr Lake, 4,89o feet, and at 5,000 feet on Mt. Washington, N. H., and at Marquette, Mich. In the series of dispar in the Le Conte Collection are two examples of this species, one from "N. H.", the other bearing the gray color disk which signifies Lake Superior.

\section{C. nigrescens sp. nov.}

Two examples ( $\delta$ ) from California, are very close to the preceding, but seem to be distinct. They are of a slightly more elongate elliptico-oval form (more obtuse at apex) and of very dark color; the head and prothorax black, elytra piceous brown, femora broadly infuscate at middle, the tarsi blackish. The sexual characters of the male tarsi are as in compar, but the large second joint is even slightly more developed. Length 3.5 to $4 \mathrm{~mm}$; width 1.8 to $1.95 \mathrm{~mm}$. The smaller measurements are those of the female.

Mono Co., California (Blaisdell), type ô.

\section{C. artus sp. nov.}

Narrowly subelliptical; fuscotestaceous above, the middle of the front, disk of prothorax and elytral margins narrowly, somewhat paler; tarsi and outer joints of antennae dusky; body black beneath, integuments polished throughout. Head and thorax finely sparsely punctate, elytra more closely and less finely punctured, the usual three series of coarser punctures very irregular, visible in basal half. Body beneath rather coarsely, not densely punctate at sides. Length $2.9 \mathrm{~mm}$.; width $\mathrm{r} .35 \mathrm{~mm}$.

\section{Mono Co., California (Blaisdell.)}

The type and only specimen at hand is a male, but the tarsi are quite narrow, the sex being revealed by the visibly modified front claw. The small size, exceptionally narrow form and narrow male tarsi are the diagnostic characters to be relied upon in this species.

\section{C. sharpi VdBr.}

Oval, strongly elongate; head black with pale spot on the vertex; thorax rufotestaceous with front and rear margins infuscate, a small discal spot behind the middle, usually confluent with the dark margin; elytra brownish fuscous or fuscotestaceous, usually nearly uniformly so, sometimes, however, with the margins paler, showing vaguely the outlines of the broadly suffused discal markings; beneath black, legs and antennae pale, the latter with the outer joints slightly dusky. Integuments polished, both above and beneath. Punctuation fine, not close, nearly uniformly distributed on head and thorax, a little coarser and denser on the elytra, the punctures gradually closer apically; discal lines of coarser punctures distinct and quite regular. Metasternum and sides of abdomen at base coarsely closely punctate, coxal plates somewhat less coarsely so. Length 3.7 to $4.3 \mathrm{~mm}$.; width $\mathrm{I} .8$ to $2 . \mathrm{Imm}$.

The type of this species is the lutescens of Sharp's Monograph, which was doubtfully identified by him as Le Conte's species, the de- 
termination based largely no doubt on the locality (San Francisco), which is the same as for Le Conte's type. Although very briefly characterized, the size, color, and narrow form, combined with the locality, leave no doubt as to what Sharp had in hand. This species is thus far known only from Central and Northern California, the localities represented in the material at hand being-San Francisco, Vine Hill, Contra Costa Co. (Blaisdell); Santa Cruz, Napa, Santa Rosa, Humboldt Co. The front and middle tarsi of the male are distinctly dilated, the first and second joints subequal in width, the third a little narrower; claws of front tarsi small, of the same form and length, the anterior one barely visibly thicker.

\section{C. suturalis Lee.}

Oval, nearly equally narrowed before and behind; dull yellowish testaceous above; black beneath; head infuscate near the eyes, leaving a triangular frontal area pale; thorax witth fuscous median spot confluent with the dark basal margin; disk of elytra broadly infuscate, the markings in the typical form completely suffused, leaving only the margins and a narrow sutiral line, paler. In many specimens the elytral markings are, however, fairly well defined. Punctuation rather dense, coarser than in ovoidcus, the irregular series of coarser elytral punctures not very distinct. Beneath coarsely, rather densely punctate. Legs either uniformly pale or with the femora somewhat clouded. Length 3.1 to $3.3 \mathrm{~mm}$; width 1.7 to $1.8 \mathrm{~mm}$.

The type series consists of three specimens taken at Lake Superior, the precise locality not named. Le Conte regarded all these as females, but a careful examination satisfies me that two of them are males. In this sex the tarsi are very slightly wider, the second joint sensibly wider than the third, while in the female joints I- 3 are of nearly equal width. The front claw of the fore tarsus is not at all modified in the male. There is a fourth specimen from "H. B. T." in the Le Conte Collection, apparently differing from the original series only in the better defined elytral markings. I have seen many examples like this last taken by Mr. J. B. Wallis in Manitoba. (Miami, Le Pas, Piquitenay River and Mile 2r4 H. B. Ry.) and others taken by Mr. Howard Notman at Cochrane in N. Ontario.

\section{C. ovoideus Lec.}

Oval, about equally narrowed before and behind, uniformly rufotestaceous above, head infuscate with pale vertex spot, thorax with basal margin darker, elytra with the sutural edge blackish, body beneath black. Punctuation rather finer and less close than in the allied species, the series of coarser punctures on the elytra evident though not very conspicuous. Length $3.5 \mathrm{~mm}$; width 1.8 to I.9 $\mathrm{mm}$.

The type locality is Eagle Harbor, Lake Superior. There are only two examples in the Le Conte Collection, both of which judging from the tarsi seem to be females. Le Conte in his description speaks of the male as being a little more shining than the female, but it may be that he 
was in error in his supposed separation of the sexes. The species is apparently rare and I have seen no other specimens than the types. In the absence of males, the tabular position is tentative only.

\section{C. canadensis sp. nov.}

Oval, moderately elongate, color above a nearly uniform piceo- or fuscotestaceous, fading into a dingy yellow at the extreme margins of the elytra, the prothorax commonly entirely dark, but sometimes with the middle narrowly paler toward the sides; head with or without a pale vertex spot; body beneath black; legs and antennae pale, the latter infuscate apically. Punctuation throughout typical of the group, a little sparser and finer than in suturalis or medialis, nearly the same as in patruelis; the irregular series of coarser punctures on the elytra present but not conspicuous. Length 3.5 to $4 \mathrm{~mm}$.; width 1.95 to 2.I $\mathrm{mm}$.

Described from a series of 23 examples taken at Winnipeg, Man., by Mr. J. B. Wallis. The fore and middle tarsi of the male are only moderately dilated, though evidently wider than in the female, the anterior claw of the fore tarsus a little thicker and slightly shorter. Females are typically shining like the males, but two examples of this sex bearing same date as shining specimens of both sexes, are opaque. These, however, are not distinguishable from opaque females of patruelis and may belong to that species, which is commonly taken by Mr. Wallis in the same locality. Canadensis is very similar in size and form to patruelis, but is, as a rule, of darker and more uniform color, and with distinctly narrower male tarsi.

\section{C. sellatus Lec.}

Oval, nearly equally narrowed before and behind; color above pale testaceous, beneath black. Head blackish each side, a pale vertex spot, and the clypcus anteriorly diffusely paler. Thorax with front margin more narrowly, base broadly infuscate, also a diffuse discal spot confluent with the dark margins. Elytra with a large fuscous blotch occupying the posterior portion of the disk, and in front of this a small elongate spot nearer the side margin than the suture. Punctuation moderate, coarser beneath as usual, the irregular series of larger punctures on the elytra variabie in development. Length 3 to $3.25 \mathrm{~mm}$; width I.65 to $1.75 \mathrm{~mm}$.

Described from Dakota. Specimens at hand are from Winnipeg and Stony Mountain, Manitoba (Wallis.) This species may, I think, always be known by the rather sharply defined posterior elytral blotch, contrasting strongly with the pale ground color of the elytra. It is rather strongly narrowed in front, nearly as in ovoideus. Suturalis is less narrowed and consequently more obtuse in front, with more extended elytral cloud and unmodified male anterior tarsal claw. In scllatus the male tarsi are rather narrow, but evidently wider than in the female, and the anterior claw is visibly stouter.

\section{C. lutescens I.ec.}

Typically a trifle smaller and narrower than medialis, with the elytral disk more 
completely infuscate, the markings reaching nearly or quite to the base; all else substantially as in medialis. Some examples are so nearly intermediate between typical forms of these two so-called species that their disposition is little more than a matter of guess work. I have observed in the numerous specimens studied that in lutescens the dark color at the sides of the head in the great majority of specimens becomes suffused across the front so as to leave a more or less isolated pale vertex spot, while in medialis, as a rule, the pale frontal triangle reaches from the clypeal margin to the vertex. Length 3.2 to $3.5 \mathrm{~mm}$. ; width 1.65 to $1.8 \mathrm{~mm}$.

Although the figures giving the extremes in length are the same for this species as for medialis, here the average length is nearer the lower limit, while in medialis the reverse is true.

Le Conte's type of lutesccns was from San Francisco. Specimens before me are from Sacramento; Athlone, Merced Co.; and Kernville, all in California.

\section{C. medialis Lee.}

Oval, color varying from albotestaceous to brownish yellow above, black beneath; head more or less infuscate at sides; prothorax with a small median fuscous spot, rarely entirely lacking, front and rear margins slightly or scarcely infuscate, more rarely broadly so; elytra with broad suffused fuscous markings, which ustually fail to attain the base, and are not infrequently so faint as to be only traceable in certain lights. Punctuation moderately close, becoming gradually a little coarser and denser posteriorly on the elytra, the sutural and first discal series of coarser punctures quite irregular and conspicuous, the second (intrahumeral) usually less marked; beneath coarsely punctate. Length 3.2 to $3.5 \mathrm{~mm}$.; width $\mathrm{I} .75$ to $2 \mathrm{~mm}$.

A common species, ranging from Middle and Southern California to Western Texas.

The type is from San Diego, Cal. Specimens before me are from San Juan, Orange Co.; Pomona; Elsinore Lake; Santa Margarita; Santa Cruz; Vine Hill, Contra Costa Co.; San Francisco; Owen's Lake; California, Williams and Cosnino Canon, Arizona; Carlin, Nevada; El Paso Texas.

The tarsi are but little wider in the male than in the female; the anterior claw of front tarsus ( 0 ) evidently a little thicker and more suddenly bent.

Specimens from Arizona and Texas are nearly uniformly pale in color, the elytral markings faint or nearly wanting; these also seem as a whole slightly more finely punctate, but there are perfect intermediates between them and the typical California coast form with heavily clouded elytra. These latter are very near lutescens, and in many cases separation is purely an arbitrary matter.

\section{C. virgo sp. nov.}

Moderately elongate oval, both sexes shining; head and thorax brownish, the former with pale vertex spot, the latter with sides paler; elytra luteous, the 
dorsal cloud broad but faint, abbreviated in front. Punctuation above moderately close, the series of coarser elytral punctures visible but not conspicuous. Beneath black, coarsely but not very closely punctate. Front tarsi moderately dilated, the first and second joints subequal in width, anterior claw slightly thicker, more strongly bent and a little shorter than the posterior one. Length 3.6 to $3.7 \mathrm{~mm}$; width 1.9 to $1.95 \mathrm{~mm}$.

Described from I $\sigma^{\star}$ (type) and $3^{\circ}$ 's from the Virgin River, Utah, the type series from the Roberts Collection kindly loaned by the American Museum of Natural History, to which the type is returned. A female paratype is retained in my own collection.

This species is of same size and general appearance as the paler forms of medialis, but is of slightly narrower form, the sides being less strongly rounded, the punctuation beneath not so coarse and close, and the male tarsi distinctly wider. It is really much more closely related to canadensis, but the clearer yellow color, with evident though faintly defined posterior elytral cloud seems at present distinctive.

\section{C. obscureplagiatus sp. nov.}

Elongate oval, about equally narrowed in front and rear, brownish ferruginous or brownish yellow, the head a little paler in front; thorax and elytra variable, the former nearly uniformly brown or piceous brown, the latter with the disk usually dark brownish with obscure piceous markings of the medialis type, the base and sides of the elytra gradually somewhat paler. Surface polished both above and beneath in the male, the females either shining like the males, or alutaceous and opaque. Head and thorax finely typically punctate, elytra more coarsely quite densely and nearly uniformly so, the series of coarser punctures represented only by a lightly impressed line at the middle of the disk in basal half, scarcely detectable in some examples. Body beneath black, coarsely closely punctate. Front and middle tarsi of male moderately widely dilated, the second joint conspicuously widest, the anterior claw a little stouter and more abruptly curved basally. Length 3.8 to $3.9 \mathrm{~mm}$; width $1.95 \mathrm{~mm}$.

Described from a series of $20^{\prime \prime} \mathrm{s}$ and $5^{\text {'? }} \mathrm{s}$ (3 shining, 2 opaque) from Port Townsend, Wash. (A. Seaton), and Portland, Oregon. (Wickham.) The type is a male from the first named locality, kindly given me by Mr. Waldo Dodge of Melrose Highlands, Mass.

This species is remarkably similar in nearly all respects to compar. The entire absence of elytral clouds (virtually absent in some specimens of obscureplagiatus, the evident disparity in elytral punctures, and the generally finer and less dense punctuation, together with the locality may be depended on to distinguish the latter.

\section{C. pedalis Fall.}

A little larger than medialis and lutescens, the form less narrowed and hence more obtusely rounded in front. Color a dingy yellow, the head, base and diffuse median spot on the prothorax, and almost the entire disk of the elytra infuscate; beneath black, epipleurae and legs dull yellow. Punctuation above quite dense, a little less so basally, the irregular series of coarser punctures evident on the elytra, the outer discal one, however, quite inconspicuous. 
Punctuation beneath coarse and dense, the epipleurae much more deinsely and completely punctate than in the allied species.

Male: front and middle tarsi very little wider than in the female, the claws of the front tarsi slender and similar; front femora flattened and broadly obliquely concave distally beneath, middle tibiae sinuate and produced inwardly at apex, hind femora without the usual fine strigosity, coarsely punctate and obliquely rugose distally.

Female: legs normal, except that the hind femora are not finely strigose.

Length 3.65 to $4.1 \mathrm{~mm}$.; width 2 to $2.15 \mathrm{~mm}$.

California. Type from Pomona. Known to me also from Riverside, Naples, San Diego (Blaisdell) ; Vine Hill, Contra Costa Co. (Blaisdell.)

The peculiar crural sexual modifications make this one of the most distinct and easily recognized species of the genus when males are at hand. Females may be known from other species occurring in same region by the more obtuse form and densely punctate epipleurae.

\section{C. collatus sp. nov.}

Moderately elongate oval, color as a rule, rather clear flavotestaccous with the usual infuscations, viz.; the outer antennal joints, sides of the front, small discal spot and basal margin of the prothorax (more or less) and the disk of the elytra; the broad confluent elytral markings distinctly outlined externally, the suture narrowly pale, at least toward the base. Surface shining in both sexes, the punctuation typical in distribution and moderate in density. Beneath black, polished, with the usual coarse lateral punctuation, which, however, is rather finer and less dense, especially on the coxal plates, than in such species as medialis, suturalis and pedalis. Front and middle tarsi of male moderately strongly dilated, the second joint of front tarsi not wider than the first; anterior claw of front tarsus very evidently thickened and more abruptly bent. Length 3.75 to $4.2 \mathrm{~mm}$.; width 1.9 to $2.15 \mathrm{~mm}$.

The type is a male taken by the writer at Bear Lake, So. California, 8-3I-'I6. I have also taken the species at Winslow, Arizona, and have an example from Cosnino Canon, Ariz., collected by Prof. Wickham.

This species is closely similar in nearly every way to patruelis, but is of somewhat larger average size, with a little less strongly dilated male tarsi, the second joint not wider than the basal one.

\section{C. patruelis Lec.}

Very similar to collatus, the description for which answers well enough except as follows: Size a little smaller, females of two forms-shining and opaquethe elytral cloud often more diffuse and ill-defined, though frequently quite as sharply outlined as in collatus. Front tarsi of male more strongly dilated, the second joint perceptibly wider than the basal one. Length 3.6 to $3.9 \mathrm{~mm}$.; width I. 8 to $2 \mathrm{~mm}$.

Le Conte's type was from "Fort Laramie, Nebraska." Specimens at hand are from Cheyenne, Wyoming (Wickham), and Winnipeg, Stony Mountain, Miami, and Thornhill, Manitoba, all collected by Mr. Wallis. 


\section{C. infuscatus Sharp.}

"Oblongo-ovalis, fere sine pubescentia, testaceous, abdomine pectoreque nigris, elytris signaturis magnis coalescentibus fuscis, dense, aequaliter subtiliter punctatis, serie punctorum impressa minus distincta; coxis posterioribus externe minus crebre punctatis. Long. 5 , lat. $2 \% 3 \mathrm{~mm}$."

The above is Sharp's description of this species, which is unknown to me in nature. The author goes on to remark that "This species is readily distinguished from $H y d r o p o r u s$ mubilus by its larger size, and more finely and densely punctured elytra. I have seen only two individuals, both of which are females, one is shining, the other dull; the front tarsi are less compressed and are broader than in the corresponding sex of mubilus." The very large size, together with the locality, will probably ensure the recognition of this species when it again turns up. Only three species of our fauna-unguicularis, impressopunctatus and oregonus - attain a length of $5 \mathrm{~mm}$.

\section{C. nubilus Lec.}

Elongate oval, yellowish testaceous, antennae scarcely at all infuscate apically; head pale, with or without a small transverse fuscous spot contiguous to the thoracic margin; prothorax with small discal spot, the front and rear margins scarcely darker; elytra with somewhat diffuse posteriorly confluent markings, consisting of two subentire vittae near the suture, exterior to which are anterior and posterior spots representing two more abbreviated and interrupted vittae. Elytral punctuation rather close and subequal throughout, the series of coarser punctures nearly or quite absent. Beneath black moderately punctate, epipleurae more closely and uniformly so than in patruelis. Front and middle tarsi of male quite strongly dilated, the second joint perceptibly wider than the first and third; anterior claw of front tarsus ( $\left.\sigma^{0}\right)$ a little shorter, thicker and more strongly bent than its fellow. Length 4 to $4.4 \mathrm{~mm}$.; width 2 to $2.2 \mathrm{~mm}$.

A common and widely diffused species, occurring from New England to Western Texas. Le Conte's type was from Fort Laramie and he speaks of its occuirrence also in Illinois. Specimens seen by me are from Massachusetts (Blanchard) ; N. Y.; Jeannett, Pa., Detroit, Mich.; McPherson Kans.; Fedor, Tex. and El Paso, Tex.

The elongate form, rather large size, evenly rather finely punctate elytra, and pale head, form a combination of characters which separate this species from all others except femoratus, from which males are easily separable by the tabular characters. In the series of mubilus before me, the few females are duller and finely alutaceous; it is, however, not unlikely that shining females occur.

\section{C. femoratus Fall.}

This species is so exactly similar to nubilus as to be quite indistinguishable except by reference to the femoral and tibial structure of the male. In this sex all the femora are sinuate beneath near the knee, the margins strongly laminate at apex. The tibiae are pedunculate at base, then suddenly widened 
and nearly parallel, instead of gradually widening from base to apex as is usual. Length $4.5 \mathrm{~mm}$; width $2.2 \mathrm{nim}$.

The type is a male, collected at Albuquerque New Mexico, by Prof. Wickham. A second example, taken at same place is a female and is probably correctly associated; it is slightly larger, and noticeably duller than the male.

\section{C. fraternus Lec.}

Rather broadly oval, pale flavo-testaceous above, black beneath; males shining, females dull. Antennae scarcely at all infuscate at tip. Head with or without a small occipital spot; prothorax with small median spot, and middle of base narrowly darker, both, however, sometimes obsolete; elytra with small discal markings, mostly behind the middle. Punctuation of elytra rather close and even, the series of larger punctures scarcely evident. Beneath coarsely closely punctate. Front and middle tarsi of male widely dilated, the second joint perceptibly wider than the first and third, anterior claw of front tarsus more strongly curved but not much thicker than the posterior one. Length 3.4 to $3.95 \mathrm{~mm}$. ; width $\mathrm{I} .9$ to $2.2 \mathrm{~mm}$.

California ("New River, Colorado Desert") (type) ; Mokelumne Hill (Blaisdell) ; Arizona (Phoenix, Palomas.)

This species seems quite characteristic of the arid and semi-arid regions of Arizona and contiguous territory. Its occurrence at Mokelumne Hill on the western side of the California Sierras was hardly to be expected. The species is most likely to be confounded with the paler forms of medialis, which occur in the same region; the latter however is rather narrower in form, with broader elytral clouds, the tarsi of the male less dilated and with somewhat differently shaped anterior claw, the females, as a rule, more shining. All females of fratermus that I have seen are alutaceous and dull.

\section{C. tumidiventris sp. nov.}

Oval, moderately convex; head, thorax and legs rufotestaceous, elytra pale flavotestaceous to dull yellow, body beneath black. Head black or fuscous at sides and vertex; prothorax with basal and apical margins sometimes narrowly infuscate, a small fuscous discal spot, rarely lacking; elytra with variable blackish or fuscous markings, which in the type consist of four well defined vittae on each, the two inner ones entire, the two outer interrupted; but in the greater number of specimens the vittae are more or less completely fused posteriorly or even throughout. Antennae with the outer joints lightly infuscate at their apices. Integuments polished in the male, in the female the surface may be either shining like the male or finely alutaceous and dull both above and beneath. Head and thorax finely sparsely punctate, elytra with intermixed fine and coarser punctures, the sutural and two discal series of coarser punctures distinct as far as the middle. Beneath moderately punctate; last ventral obtusely tumid each side, the tumidity stronger and more punctate in the male. Front and middle tarsi of male rather strongly dilated, the second joint widest, but less conspicuously so than in the three preceding species. Length 4.2 to $4.5 \mathrm{~mm}$.; width 2.15 to $2.4 \mathrm{~mm}$. 
Described from a series of 50 "s and 4\%'s, two of the latter opaque. The type ( $\left.\delta^{\prime}\right)$ bears label "Stony Mountain, Man. I5-IV-12, J. B. Wallis." Other localities represented are Edmonton, Alberta, April 8, I9I6 (F. S. Carr); Wy.; Glenwood Springs, Colorado (Fenyes); and Virgin River, Utah (Roberts Coll.)

The rather large size, dual elytral punctuation and tumid terminal ventral segment perfectly define this species.

\section{C. punctilineatus sp. nov.}

Oval, pale flavotestaceous above, black beneath, surface ( $($ ) both above and beneath alutaceous and dull. Head black each side, leaving a triangular frontal area pale; thorax with a small discal dot and the extreme edge of the basal margin at middle, piceous; elytra each with four narrow vittae and the suture, black; outer vittae interrupted at middle. Punctuation above very fine, with coarser punctures along the suture basally, and elsewhere for the most part confined to the black vittae, especially apically. Beneath moderately punctate, most strongly and closely on the coxal plates. Length $3.6 \mathrm{~mm}$.; width $1.95 \mathrm{~mm}$.

Described from a single female specimen taken by Mr. J. B. Wallis at Stony Mountain, Manitoba, April 13, I912.

The front tarsi of the female are moderately dilated and it is probable that they are quite widely so in the male. This species is most closely allied to tumidicentris, but the size is notably smaller, the punctuation very much finer, the coarser punctures of the elytra fewer and differently disposed, and the last ventral without trace of the apical tumidities.

\section{C. masculinus Cr.}

Elongate, slightly obovate, elytra pale flavotestaceous, head and thorax a little more rufous, beneath black. Surface shining in the male, finely alutaceous and dull in the female. Punctuation of head and thorax fine, not dense, very slightly coarser along the base of the latter; elytra finely, quite densely and very evenly punctate, the series of coarser punctures entirely lacking. Head entirely pale, clypeus finely margined. Prothorax a little narrower at base than the contiguous base of the elytra, sides feebly arcuate or nearly straight, not very strongly convergent in front and not continuous with the sides of the elytra; base very narrowly dusky at middle, otherwise entirely pale. Elytra each with four narrow vittae and the suture, black; vittae I and 3 abbreviated at base, 4 abbreviated apically, 3 and 4 with a tendency toward interruption at middle. Body beneath finely alutaceous, sides of metasternum, sides of abdomen at base, and last ventral segment more coarsely punctate, elsewhere sparsely finely punctate. Anterior tarsi of male rather strongly dilated, the claws very long, broadly laminiform, dilated at middle, the anterior one a little shorter and less acnte at tip. Length $4.5 \mathrm{~mm}$.; width $2.3 \mathrm{~mm}$.

Crotch's type was described from Lake Lebache, the precise location of which is unknown to me but presumably in British Columbia or Alberta. In my own collection this quite remarkable species is represented by a single pair, the male from Dakota and female from Winnipeg, Man. (Wallis.) 
In addition to the several characters given in the table, it may be added that in this and the following species, the spines along the inner edge of the basal joint of the hind tarsus are shorter and more close set than in any other species known to me.

\section{C. fastidiosus sp. nov.}

Very closely allied to masculinus and possibly to be united with it as a local variety when further specimens including males are known. The form is a little less distinctly obovate, the prothorax larger, sides longer, just perceptibly sinuate, and continuous with the sides of the elytra, feebly subexplanate, especially toward the anterior angles; not in the least so in masculimus. Length $4.7 \mathrm{~mm}$. ; width $2.4 \mathrm{~mm}$.

A single female specimen collected at Owen's Lake, California, V-22I7 by G. R. Pilate.

\section{C. semivittatus sp. nov.}

Moderately elongate, slightly obovate, pale flavotestaceous, the head and thorax of slightly brighter tint and entirely immaculate; elytra each narrowly quadri vittate with fuscous posteriorly, the two inner vittae on each extending to a point a little in advance of the middle, the two outer ones represented only by one or two short fragments, the suture also narrowly dark, surface (q) very finely alutaceous and dull both above and beneath. Antennae with the outer joints partly infuscate. Prothorax small, strongly transverse, sides nearly straight, only slightly divergent posteriorly and not continuous in outline with the elytra. Head and thorax very finely, not closely punctate, elytra densely evenly so, almost without trace of coarser punctures. Length $4.5 \mathrm{~mm}$.; width $2.2 \mathrm{~mm}$.

The unique female type was taken by the writer at Seligman, Arizona, July 3, I906.

The four anterior tarsi are narrow, the first three joints elongate parallel and of equal width. It is quite possible that further specimens will show that the elytral vittae are not constant in their degree of development. The somewhat obovate form and small thorax with sides discontinuous in outline with the elytra, are quite suggestive of masculinus, but the structure of the clypeus, prosternal process and basal joint of hind tarsus are normal in the present species.

\section{C. hudsonicus sp. nov.}

Moderately elongate oval or feebly obovate, dull yellowish testaceous, head more or less infuscate at sides, thorax witth small discal spot, elytra each with four vittae and the suture piceous, body beneath black. Upper surface of male finely reticulato-alutaceous and moderately shining, in the female more distinctly alutaceous and dull. Elytra evenly, rather closely punctate, coarser punctures scarcely evident; head and thorax more finely and sparsely punctate as usual. Beneath alutaceous and rather sparsely, not very coarsely punctate. Front and middle tarsi of male broadly dilated, the second joint widest, the claws more elongate than usual, the anterior one curved and a little shorter than the posterior, which is ncarly straight. In the female the claws of the front tarsi are much shorter than in the male, and equal. Length 3.8 to 4 mm.; width 1.85 to $1.95 \mathrm{~mm}$. 
Desscribed from a single pair (the female smaller) taken at Ungava Bay, H. B. T., by L. M. Turner.

A quite distinct species, though evidently allied to unguicularis. The latter is much larger, less elongate, and with different front claws in the male.

\section{C. unguicularis $\mathrm{Cr}$.}

Form oval, not or scarcely twice as long as wide, fulvotestaceous above, black beneath. Male shining, female dull. Head at the extreme base, a small discal spot and the middle of the base of the prothorax, and the suture and four vittae on each elytron blackish or fuscous. The elytral vittae are rather wide, the outermost one shortest, interrupted at middle and often more or less confluent with the next inner one. Head and thorax not very closely punctulate, the punctures a little closer along the thoracic base; elytra densely, rather finely punctate, without series of coarser punctures. Beneath alutaceous in both sexes, punctuation moderate in coarseness, typical in distribution. Front tarsi of male broadly dilated, the second joint, not or only just perceptibly wider than the first both claws stout, acuminate, the anterior one but little more than half as long as the other. Length 5 to $5.5 \mathrm{~mm}$.; width 2.6 to $2.8 \mathrm{~mm}$.

Crotch's type was from British Columbia. Specimens at hand are from Winnipeg, Le Pas, and Mile 214 H. B. Ry., Manitoba; Overland Lake, Boulder Co., Colorado (Rohwer.)

This is a very distinct and easily recognized species when due attention is paid to its characters. It is our largest species with the exception of impressopunctatus and oregonus. Certain examples of tumidiventris approach the smaller specimens of unguicularis and look quite similar but the resemblance is only superficial.

\section{C. oregonus sp. nov.}

Elongate oval, dull yellowish testaceous, shining ( $\left.\delta^{\prime}\right)$, elytra each with four rather wide fuscous stripes showing a tendency to confluence, the suture also very narrowly dark. Head and thorax pale, almost throughout, a small discal fuscous spot on the latter. Punctuation of elytra moderately close, rather fine, without distinct series of coarser punctures; head and thorax more finely and sparsely punctate as usual. Body beneath black, not alutaceous, moderately coarsely punctate. Front tarsi of male broadly dilated, the second joint scarcely visibly wider than the first, claws short, stout, evenly curved and mutually equal. Length $5.8 \mathrm{~mm}$.; width $2.85 \mathrm{~mm}$.

Corvallis, Oregon. A single male specimen submitted by $\mathrm{Mr}$. Sherman, who retains the type.

Slightly larger and more elongate, but very similar to unguicularis superficially. The size, vittate elytra, shining non-alutaceous lower surface, and short, stout, equal claws of male front tarsi are sufficient for its easy recognition.

\section{C. impressopunctatus Schall.}

Oblong oval, above yellowish testaceous, to dark ferruginous, head at sides and behind, and base of thorax more or less infuscate; elytra either more or 
less evidently vittate or with the vittae suffused into a broad dorsal cloud, or with the entire surface brownish piceous; beneath black. Head finely punctate; prothorax unevenly punctured, finely so in front, with numerous coarser punctures in the basal region; elytra in the male with fine and much coarser punctures conspicuously intermixed with the usual discal lines of coarse punctures regular and impressed in basal half, becoming obsolete at or behind the middle. In the female the elytra are generally more densely punctate and dull, the intermixed fine punctures less evident and the impressed discal lines feeble or wanting; some females, however, have the elytra shining and punctate as in the male. Beneath moderately coarsely punctate, alutaceous, opaque in the dull females, more shining in the males. Tarsi rather broad in both sexes, but evidently wider in the male, the basal joint slightly narrower than the second, the anterior claw of the front tarsus ( $\left.\sigma^{1}\right)$ thicker and more strongly curved, apparently shorter than its fellow when viewed from the front. Length 4.5 to $5.4 \mathrm{~mm}$. ; width 2.3 to $2.7 \mathrm{~mm}$.

A very widely dispersed species, occurring from New England to Alaska in this country, as well as in Siberia, Asia Minor and Northern Europe.

There is a great deal of variation in form, color, markings and sculpture as might be expected in a species of circum-terrestrial dispersion. 

RETURN BIOLOGY LIBRARY

TO $\Rightarrow 3503$ Life Sciences Bldg. 642.2531

LOAN PERIOD $1 / 2$

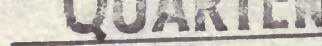

$\overline{4}$

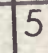

6

ALL BOOKS MAY BE RECALLED AFTER 7 DAYS Renewed books are subject to immediate recall

DUE AS STAMPED BELOW

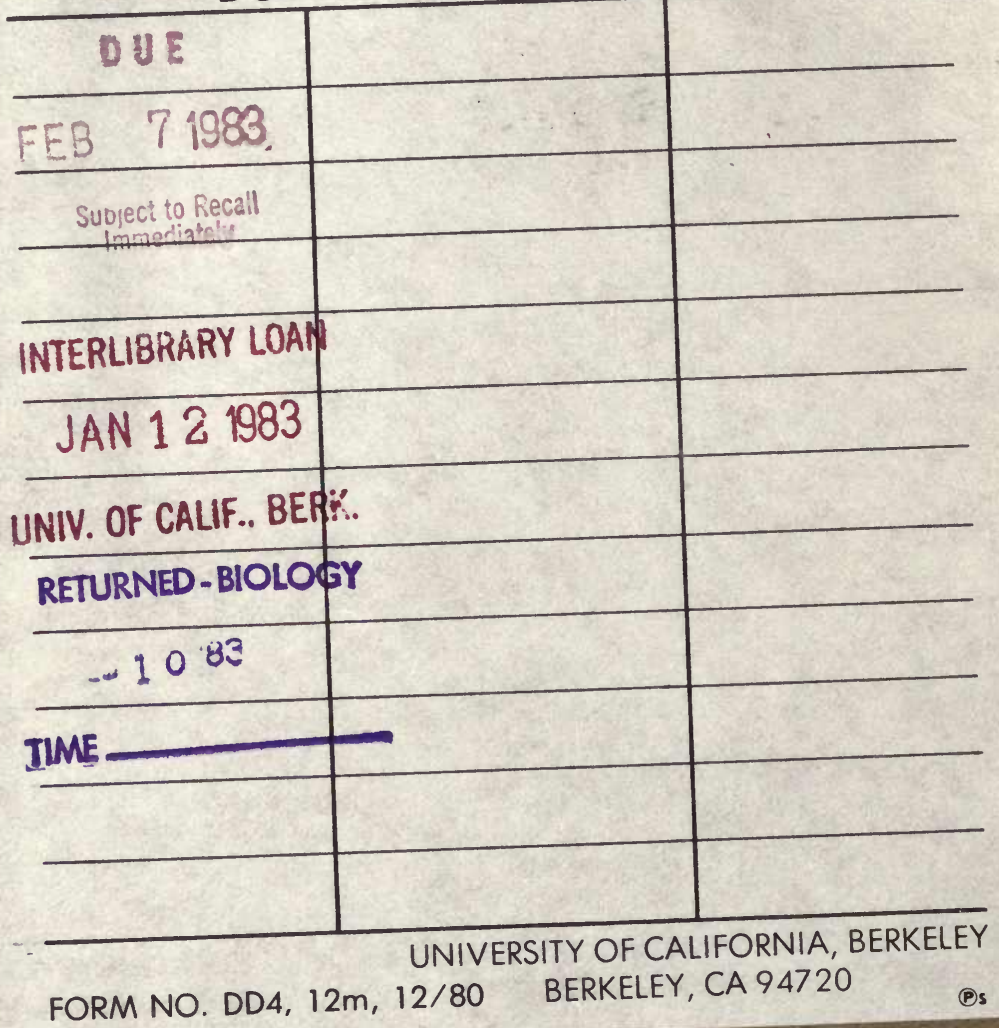




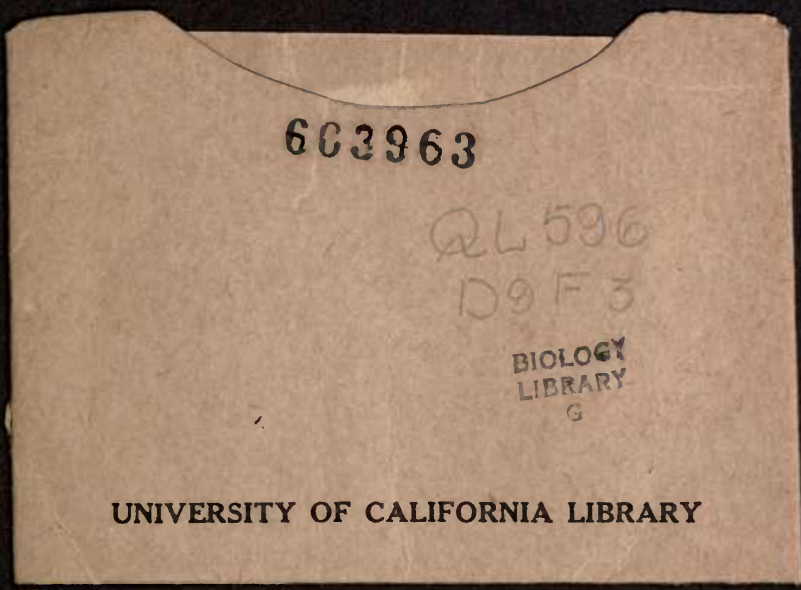


